\title{
Nutrient uptake analysis of black cohosh (Actaea racemosa L.) grown under shade in greenhouse
}

\author{
Julia Robinson ${ }^{1}$, Guochen Yang ${ }^{1,2}$, Sanjun $\mathrm{Gu}^{1}$, Zhongge (Cindy) Lu ${ }^{1}$, and Bryce Holmes ${ }^{1}$ \\ College of Agriculture and Environmental Sciences, North Carolina A\&T State University, Greensboro, North \\ Carolina, USA
}

\section{*Corresponding author: yangg@ncat.edu}

\begin{abstract}
This research was determining optimal fertilizing strategies for Black cohosh, as an herbal alternative for menopause, to increase crop productivity. Nutrient uptake was analyzed on one-year old plants grown under $80 \%$ shade in a greenhouse and exposed to two nutrient application treatments: single and continuous exposures of fertilizer at $0 \%, 2 \%, 4 \%, 6 \%, 8 \%$ and $10 \%$ concentrations during a one-year study. Two respective experimental designs were used for growth data and nutrient uptake analysis. Growth data was using a Completely Randomized Split Plot Design, with two treatment groups, single exposure and continuous exposures of fertilizer, and six subplots for each concentration. Nutrient uptake analysis was using a Completely Randomized Design and conducted only on single exposure fertilizer treatment for total amount of calcium, iron, potassium, magnesium, manganese and zinc. Single exposure (5 replications) of fertilizer had one application of fertilizer solution per concentration, to soil, one week before planting, while continuous exposure (7 replications) of fertilizer had an initial application of fertilizer solution one week before planting and subsequent application of fertilizer solution per concentration, once a week for entire growing season. Continuous exposure led to a significant decrease in growth and rhizome weights, and a significant increase in stem number per plant as fertilizer concentration increased. No growth change was observed with a single exposure of fertilizer, except for a decrease in stem length. Black cohosh mainly utilizes calcium, potassium, magnesium and zinc as it fully matured, and manganese since initial growing stage. Calcium and magnesium accumulated primarily in leaves, while potassium accumulated in stem and iron in rhizome.
\end{abstract}

Keywords: Actaea racemosa; Black cohosh; elemental composition; medicinal plant; nutrient uptake.

\section{Introduction}

Actaea racemosa L., commonly known as Black cohosh, has been successfully cultivated before, but not on a wide scale, making it important to determine what growth strategy will work most efficiently (Gardner, 2002). This is especially important for those in charge of areas where uncontrolled (wild) harvesting practices of Black cohosh have resulted in habitat degradation. It is not uncommon for wild harvesters to completely strip a single area of wild Black cohosh, thereby reducing the potential for regrowth (Schwalbach, 2005). Efforts to control harvesting have mainly focused on limiting the amount of plant material that can be harvested and the amount of time given through permits, such as ones from the North Carolina Forest Service.

Black cohosh is an important source material used by the herbal products industry (Adam, 2004). It is currently the main herbal alternative for women undergoing menopause in place of hormone replacement therapy. Burdette et al. (2003) reported that hormone replacement therapy has been associated with increases in chances of breast cancer, coronary heart disease, stroke and pulmonary embolism. Black cohosh, alternatively, has been used since before the 1800s in North America to help prevent menopausal symptoms in women, and Europeans have been using Black cohosh ethanolic and isopropanolic extracts for more than 40 years (Predny et al., 2006). Concerns about potential liver toxicity from Black cohosh were dispelled by Foster's (2013) report for the American Botanical Council, which showed that liver toxicity was caused by the adulteration of Black cohosh in cheaper, exported medicine, and that there was only a weak or uncertain causal link, or no causal link at all, between true Black cohosh and liver toxicity.

It is important, then, that pharmaceutical companies obtain plant material from local, vetted sources, decreasing the chance of harm from adulterated or mislabeled plants, especially because of the recent revival of herbal products in modern medicine (Queralt et al., 2005). To reduce these possibilities, Black cohosh needs to be cultivated in conventional growing environments. The nutrient uptake and exact fertilization formula for Black cohosh can be valuable information for plant cultivation. This is especially important due to Black cohosh's status as a medicinal herb, because 
micronutrient composition of medicinal plants is fundamental to understanding modes of action in medicinal plants (Tiwari and Rao, 2002). Determining the nutrients and the necessary fertilizer treatments needed to optimally grow Black cohosh would help determine a plan of action for successfully cultivating the herb on a higher scale. It would also potentially prevent over or under fertilizing these medicinal plants in a way so that it does not decrease the pharmacological effect of Black cohosh (Queralt et al., 2005). Studying the relative nutrient uptake of Black cohosh is done in a controlled setting, such as a greenhouse, and in individual pots to determine the uptake of a single plant, allowing a fertilization strategy to be developed. The combination of primary nutrients, secondary nutrients, and micronutrients are important to promote the efficient growth of plants. Fertilizers are used to increase essential elements in soil and to "stimulate healthy, vigorous growth" (Crouse and Myers, 2016). This study was focused on measuring the effect of a commercial fertilizer application over time on plant growth and the nutrient uptake of Black cohosh, thus determining the correlation of plant growth and nutrient uptake. This project studied the nutrients indicated on the label of the fertilizer, i.e. Calcium (Ca), Iron (Fe), Potassium (K), Magnesium (Mg), Manganese (Mn), and Zinc (Zn), nutrients that are considered essential for plant growth (Reid, 2001; Jakobsen, 1992).

\section{Results and Discussion}

This study examined the effects of a commercial fertilizer on the growth of Black cohosh and determined the nutrient uptake of the herb at different stages of the plant life cycle. The hypothesis was that excessively fertilizing plants would adversely affect plant growth and that a single exposure of fertilizer, at $10 \%$ concentration, would promote the most vigorous plant growth. No widespread commercial fertilizer has been recognized for the cultivation of Black cohosh, however fertilizers have been deemed "often indispensable in order to obtain large yields" in medicinal and aromatic plants (Switzerland, 2003). The commercial fertilizer used was Fusion 360 Gold SunBurst Company Fertilizer, which promoted supplying preformed nutrients to plants, and was tested at six different concentrations with a control that had no added fertilizer solution. Plants were also separated into two groups: those that would be treated continuously (once a week until the plants died or went dormant), and those that had only a single treatment exposure at the initiation of planting.

\section{Nutrient uptake of Black cohosh life cycle}

Nutrient uptake was analyzed in plant parts that were treated once with fertilizer solutions using the ICP-OES instrument. Data was analyzed at five stages (Pre-treatment of soil, preplanting, new growth (>75\%), full maturity $(>90 \%)$, and death or dormancy) of the plants life cycle and was summarized in Table 1 indicating how much is in the soil; how much is taken up by the plant as it begins to grow; and then, what returns to the soil after death or dormancy of the plant. As Black cohosh matured, calcium, potassium, magnesium and zinc were taken up by the plant, while iron remained mainly in the soil and manganese was taken up by the plant as it began to grow, but returned to the soil as it began to die. Significant change was determined at the 0.05 level of significance and indicated how different elements significantly changed among fertilizer concentrations (Tables $1 \& 2$ ). The mean amount of calcium was not affected by fertilizer solution concentration, however there was an increase in calcium amount at full maturity (stage 4) of plant growth for fertilizer solutions $6-10 \%$ (Table 1). Zinc, while found in trace amounts, is an essential micronutrient, and its use in medicinal plants is actually enhanced when incorporated in mineral complexes (Imelouane et al., 2011). There was a significant decrease in iron from plant samples at stage 4 of plant growth when compared to previous stages soil samples, and there was a significant change between all stages of plant growth for $8 \%$ and $10 \%$ fertilizer solution. Potassium and zinc both had a significant increase in total element amount at stage 4 of plant growth for all fertilizer solutions, except $10 \%$ fertilizer solution for zinc where there was a significant change between all stages of plant growth. Manganese demonstrated significant change for all stages of plant growth at all fertilizer solutions except for $8 \%$ fertilizer, which demonstrated no significant change (Fig 1). Magnesium demonstrated no significant change for the different stages of plant growth for any of the fertilizer solutions. Nutrient uptake analysis indicated that Black cohosh mainly utilizes calcium, potassium, magnesium and zinc as it fully matures, as well as manganese during its initial growing until full maturity. Studies on medicinal plants, such as Black cohosh, have previously determined that elements such as calcium, magnesium and iron are essential to plant growth (Mathe, 2015). Iron, however, was not taken up with the same tenacity as calcium and magnesium (Tables $1 \& 2$ ). According to Morrissey and Guerinot (2009), this was potentially because the $\mathrm{pH}$ of the soil medium that the plants were grown in caused iron to be insoluble and unavailable for the plants to uptake. Further studies are necessary to test this uptake on a $\mathrm{pH}$ gradient, to determine if Black cohosh needs more iron for optimum growth.

\section{Nutrient uptake of different parts of plant}

Table 2 measures the amount of element found in each part of the plant (leaf, stem and root) at full maturity (stage 4) of the plant's life cycle, to determine where the elements are concentrating in the plant. Calcium and zinc accumulated in the leaves of the plant, iron accumulated almost exclusively in the roots of the plant, and potassium accumulated in the stem. Trace amounts ( $<2 \%$ of total element composition) of manganese and zinc were found in all parts of the plant at each stage of plant growth.

\section{Effect of fertilizer on plant growth}

Our data indicated that there were significant changes in plant growth among fertilizer concentration for the continuous treatment. Stem length, stem diameter, rhizome fresh and dry weight all gradually decreased as fertilizer concentration increased, except for number of stems which increased as fertilizer concentration increased (Figs 1, 2, 3, and 4). Canopy size (Fig 5) noticeably decreased as fertilizer increased, and the number of leaves had a noticeable decrease in number from $4 \%$ to $6 \%$ fertilizer solution (Fig 4 ). For single exposure as 
Table 1. Average amount (mg/kg) of elements ( $\mathrm{Ca}, \mathrm{Fe}, \mathrm{K}, \mathrm{Mg}, \mathrm{Mn}$, and $\mathrm{Zn}$ ) by fertilizer concentration and stage of plant development.

\begin{tabular}{|c|c|c|c|c|c|c|}
\hline & & Stage 1 & Stage 2 & Stage 3 & Stage 4 & Stage 5 \\
\hline \multirow[t]{6}{*}{$0 \%$} & $\mathrm{Ca}$ & $5488.6^{\mathrm{a}}$ & $5208.8^{\mathrm{a}}$ & $4258.8^{\mathrm{a}}$ & $11923.6^{\mathrm{a}}$ & $5145.4^{\mathrm{a}}$ \\
\hline & $\mathrm{Fe}$ & $16561.0^{\mathrm{a}}$ & $12546.9^{a}$ & $11702.0^{\mathrm{a}}$ & $1825.1^{b^{*}}$ & $11366.4^{a}$ \\
\hline & $\mathrm{K}$ & $5247.9^{a}$ & $3797.8^{a}$ & $3080.8^{a}$ & $22040.3^{\mathrm{b}^{*}}$ & $3105.1^{a}$ \\
\hline & Mg & $17890.8^{\mathrm{a}}$ & $14862.1^{\mathrm{a}}$ & $13425.9^{\mathrm{a}}$ & $9744.1^{a}$ & $12543.3^{\mathrm{a}}$ \\
\hline & $\mathrm{Mn}$ & $237.8^{\mathrm{a}}$ & $167.3^{\mathrm{ac}}$ & $100.6^{b c}$ & $59.0^{\mathrm{b}}$ & $231.7^{\mathrm{a}}$ \\
\hline & $\mathrm{Zn}$ & $34.3^{\mathrm{a}}$ & $30.4^{\mathrm{a}}$ & $0.0^{\mathrm{a}}$ & $133.2^{\mathrm{b}^{*}}$ & $36.8^{a}$ \\
\hline \multirow[t]{6}{*}{$2 \%$} & $\mathrm{Ca}$ & $4975.9^{\mathrm{a}}$ & $5355.8^{\mathrm{a}}$ & $3642.0^{a}$ & $14391.4^{a}$ & $6354.7^{\mathrm{a}}$ \\
\hline & $\mathrm{Fe}$ & $9819.3^{\mathrm{a}}$ & $8245.6^{a}$ & $8996.1^{\mathrm{a}}$ & $1390.5^{b^{*}}$ & $11454.8^{a}$ \\
\hline & K & $2539.8^{a}$ & $2672.4^{a}$ & $2282.2^{\mathrm{a}}$ & $21425.4^{b^{*}}$ & $3116.4^{a}$ \\
\hline & $\mathrm{Mg}$ & $12147.0^{\mathrm{a}}$ & $10686.1^{a}$ & $9381.4^{a}$ & $8982.8^{a}$ & $11728.0^{\mathrm{a}}$ \\
\hline & $\mathrm{Mn}$ & $196.6^{\mathrm{ac}}$ & $117.9^{\mathrm{ac}}$ & $20.2^{\mathrm{ab}}$ & $68.7^{\mathrm{ab}}$ & $179.3^{c}$ \\
\hline & $\mathrm{Zn}$ & $14.7^{\mathrm{a}}$ & $0.7^{\mathrm{a}}$ & $0.0^{\mathrm{a}}$ & $108.2^{\mathrm{b}^{*}}$ & $35.5^{\mathrm{a}}$ \\
\hline \multirow[t]{6}{*}{$4 \%$} & $\mathrm{Ca}$ & $6208.5^{a}$ & $6655.7^{\mathrm{a}}$ & $4394.7^{\mathrm{a}}$ & $16686.2^{\mathrm{a}}$ & $6008.3^{\mathrm{a}}$ \\
\hline & $\mathrm{Fe}$ & $13217.8^{\mathrm{a}}$ & $12129.5^{\mathrm{ab}}$ & $9133.6^{\mathrm{b}}$ & $1073.0^{c^{*}}$ & $11122.9^{\mathrm{ab}}$ \\
\hline & K & $4179.7^{a}$ & $3898.0^{\mathrm{a}}$ & $2424.0^{\mathrm{a}}$ & $20399.4^{b}$ & $3031.6^{\mathrm{a}}$ \\
\hline & $\mathrm{Mg}$ & $16403.8^{a}$ & $14945.5^{a}$ & $10776.4^{a}$ & $9015.2^{\mathrm{a}}$ & $11735.5^{\mathrm{a}}$ \\
\hline & $\mathrm{Mn}$ & $201.7^{\mathrm{ac}}$ & $172.0^{\mathrm{ac}}$ & $34.3^{\mathrm{ab}}$ & $34.5^{\mathrm{b}}$ & $256.3^{\mathrm{c}^{*}}$ \\
\hline & $\mathrm{Zn}$ & $15.4^{\mathrm{a}}$ & $7.6^{\mathrm{a}}$ & $0.0^{\mathrm{a}}$ & $87.0^{\mathrm{b}}$ & $37.0^{\mathrm{a}}$ \\
\hline \multirow[t]{6}{*}{$6 \%$} & $\mathrm{Ca}$ & $4475.5^{a}$ & $6949.7^{\mathrm{a}}$ & $4718.6^{\mathrm{a}}$ & $21938.9^{\mathrm{a}}$ & $6176.7^{\mathrm{a}}$ \\
\hline & $\mathrm{Fe}$ & $7201.6^{a b}$ & $8214.1^{\mathrm{a}}$ & $11119.8^{a}$ & $1470.7^{\mathrm{ab}}$ & $12044.4^{a}$ \\
\hline & $\mathrm{K}$ & $2158.3^{\mathrm{ab}}$ & $2581.2^{\mathrm{ab}}$ & $2923.2^{\mathrm{ab}}$ & $19824.0^{\mathrm{a}}$ & $3183.6^{\mathrm{ab}}$ \\
\hline & $\mathrm{Mg}$ & $9295.0^{a}$ & $11011.9^{\mathrm{a}}$ & $12087.8^{\mathrm{a}}$ & $11459.8^{\mathrm{a}}$ & $13555.4^{\mathrm{a}}$ \\
\hline & $\mathrm{Mn}$ & $103.2^{\mathrm{a}}$ & $722.9^{a}$ & $501.9^{a}$ & $41.2^{\mathrm{ab}}$ & $180.8^{\mathrm{ab}}$ \\
\hline & $\mathrm{Zn}$ & $0.0^{\mathrm{a}}$ & $0.9^{\mathrm{a}}$ & $0.0^{\mathrm{a}}$ & $93.3^{b}$ & $35.1^{\mathrm{a}}$ \\
\hline \multirow[t]{6}{*}{$8 \%$} & $\mathrm{Ca}$ & $5086.5^{a}$ & $8071.5^{\mathrm{a}}$ & $5404.3^{a}$ & $21308.2^{a}$ & $4231.0^{\mathrm{a}}$ \\
\hline & $\mathrm{Fe}$ & $12293.6^{a}$ & $7804.0^{\mathrm{a}}$ & $6844.4^{\mathrm{a}}$ & $1372.1^{b^{*}}$ & $7033.8^{\mathrm{a}}$ \\
\hline & K & $3764.2^{\mathrm{ab}}$ & $2645.1^{\mathrm{a}}$ & $1601.9^{\mathrm{a}}$ & $22366.6^{b}$ & $2093.4^{\mathrm{a}}$ \\
\hline & Mg & $14431.5^{\mathrm{a}}$ & $11145.7^{\mathrm{a}}$ & $8081.4^{\mathrm{a}}$ & $9155.7^{\mathrm{a}}$ & $8145.2^{\mathrm{a}}$ \\
\hline & $\mathrm{Mn}$ & $212.1^{\mathrm{a}}$ & $118.6^{\mathrm{a}}$ & $82.5^{\mathrm{a}}$ & $32.2^{\mathrm{a}}$ & $108.8^{\mathrm{a}}$ \\
\hline & $\mathrm{Zn}$ & $7.2^{\mathrm{ab}}$ & $0.0^{\mathrm{a}}$ & $0.0^{\mathrm{a}}$ & $102.5^{b}$ & $47.5^{\mathrm{ab}}$ \\
\hline \multirow[t]{6}{*}{$10 \%$} & $\mathrm{Ca}$ & $4546.1^{\mathrm{a}}$ & $8498.4^{a}$ & $5822.9^{\mathrm{a}}$ & $18781.6^{\mathrm{a}}$ & $8765.3^{\mathrm{a}}$ \\
\hline & $\mathrm{Fe}$ & $10319.4^{a c}$ & $5550.8^{a}$ & $7972.9^{\mathrm{a}}$ & $1335.4^{b}$ & $12725.3^{c}$ \\
\hline & $\mathrm{K}$ & $3357.3^{\mathrm{a}}$ & $1641.0^{\mathrm{a}}$ & $2095.7^{\mathrm{a}}$ & $19919.9^{b^{*}}$ & $3342.0^{\mathrm{a}}$ \\
\hline & $\mathrm{Mg}$ & $12608.1^{\mathrm{ab}}$ & $8046.2^{\mathrm{ab}}$ & $9424.8^{\mathrm{ab}}$ & $6487.8^{b}$ & $13093.5^{\mathrm{a}}$ \\
\hline & $\mathrm{Mn}$ & $303.6^{\mathrm{ac}}$ & $89.4^{b c}$ & $8.3^{\mathrm{b}}$ & $59.2^{\mathrm{b}}$ & $199.2^{c}$ \\
\hline & $\mathrm{Zn}$ & $4.6^{\mathrm{ac}}$ & $0.0^{\mathrm{a}}$ & $0.0^{\mathrm{a}}$ & $57.5^{\mathrm{bc}}$ & $54.8^{c}$ \\
\hline
\end{tabular}

Rhizome Fresh and Dry Weight vs. Single \& Continuous Fertilizer Treatment

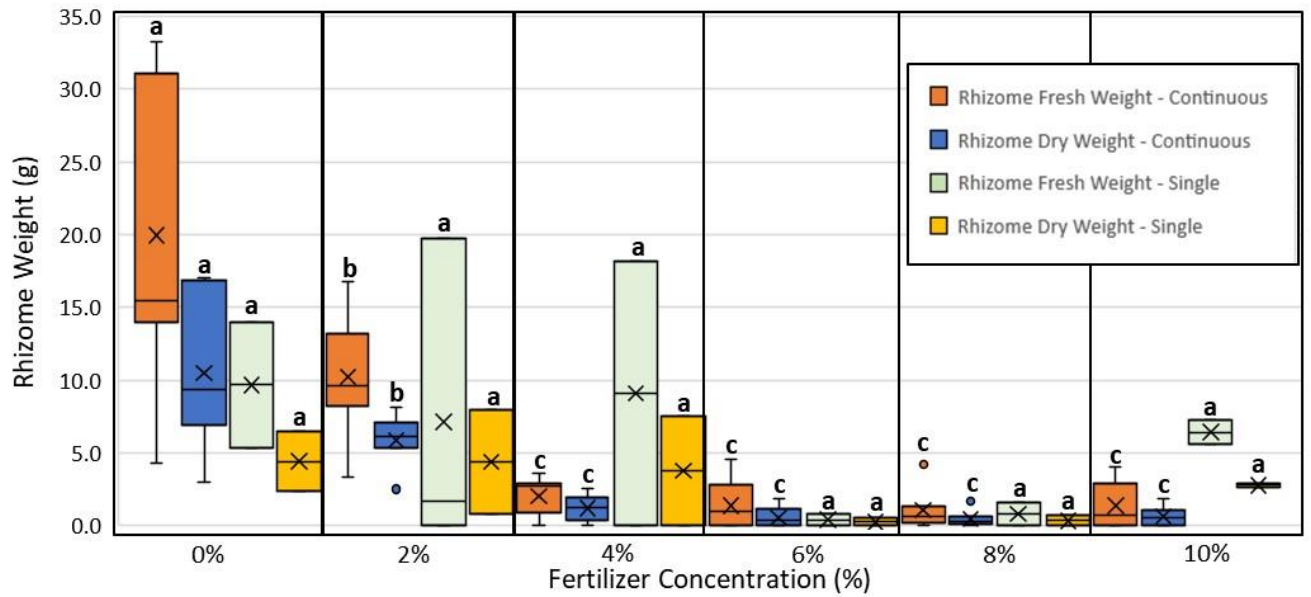

Fig 1. Mean weight of fresh and dry Black cohosh rhizomes by single or continuous treatment of Fusion 360 gold fertilizer solution by concentration. Fresh rhizome continuous treatment $P$ Value is 0.0001 ; fresh rhizome single treatment $P$ Value is 0.6595 ; dry rhizome continuous treatment $P$ Value is 0.0001 ; dry rhizome single treatment $P$ Value is 0.6380 . Level of significance was determined between each rhizome group: rhizome fresh weight continuous, rhizome dry weight continuous, rhizome fresh weight single, and rhizome dry weight single across fertilizer concentrations. Means having a letter in common are not significantly different at the $5 \%$ level of significance as indicated by Fishers protected LSD test. ntly different at $1 \%$ level of significance as indicated by Fishers protected LSD test. 
Table 2. Average amount (mg/kg) of elements ( $\mathrm{Ca}, \mathrm{Fe}, \mathrm{K}, \mathrm{Mg}, \mathrm{Mn}$, and $\mathrm{Zn}$ ) by fertilizer concentration at Stage 4 of plant development

\begin{tabular}{|c|c|c|c|c|c|c|}
\hline $\begin{array}{l}\text { Conc. Of Fusion } 360 \text { Gold } \\
\text { Fertilizer }\end{array}$ & $\mathrm{Ca}$ (mg/kg) & $\mathrm{Fe}(\mathrm{mg} / \mathrm{kg})$ & $\begin{array}{l}\mathrm{K} \\
(\mathrm{mg} / \mathrm{kg})\end{array}$ & $\mathrm{Mg}(\mathrm{mg} / \mathrm{kg})$ & $\mathrm{Mn}(\mathrm{mg} / \mathrm{kg})$ & $\mathrm{Zn}(\mathrm{mg} / \mathrm{kg})$ \\
\hline \multicolumn{7}{|l|}{ Leaf } \\
\hline $0 \%$ & $11160.3^{b}$ & $5982.9^{\mathrm{NS}}$ & $6654.3^{\mathrm{NS}}$ & $12608.2^{\mathrm{a}}$ & $146.1^{a}$ & $47.5^{a}$ \\
\hline $2 \%$ & $28186.6^{\mathrm{ab}}$ & $596.5^{\mathrm{NS}}$ & $15783^{\text {NS }}$ & $16529.1^{\mathrm{a}}$ & $30.1^{\mathrm{ab}}$ & $99.4^{\mathrm{ab}}$ \\
\hline $4 \%$ & $13677^{\mathrm{ab}}$ & $7343.2^{\mathrm{NS}}$ & $6223.5^{\mathrm{NS}}$ & $13869.8^{a}$ & $127^{b}$ & $37.4^{\mathrm{ab}}$ \\
\hline $6 \%$ & $37509.8^{\mathrm{ab}}$ & $285.2^{\mathrm{NS}}$ & $15003^{\mathrm{NS}}$ & $18701.6^{a}$ & $26.7^{b}$ & $101.1^{\mathrm{ab}}$ \\
\hline $8 \%$ & $41655.7^{\mathrm{a}}$ & $302.4^{\mathrm{NS}}$ & $13150.6^{\mathrm{NS}}$ & $15651.1^{\mathrm{a}}$ & $18.4^{b}$ & $102.3^{\mathrm{ab}}$ \\
\hline $10 \%$ & $37141.7^{\mathrm{ab}}$ & $204.8^{\text {NS }}$ & $16612.5^{\text {NS }}$ & $10073.9^{b}$ & $31.9^{\mathrm{ab}}$ & $61.5^{b}$ \\
\hline \multicolumn{7}{|l|}{ Root } \\
\hline $0 \%$ & $9374.2^{b}$ & $4310.9^{\mathrm{NS}}$ & $25149.1^{\text {NS }}$ & $8390.6^{\mathrm{NS}}$ & $105.2^{\mathrm{NS}}$ & $143.3^{a}$ \\
\hline $2 \%$ & $7200.9^{b}$ & $8971.3^{\mathrm{NS}}$ & $8608.5^{\mathrm{NS}}$ & $11167.5^{\text {NS }}$ & $171.7^{\mathrm{NS}}$ & $45.3^{\mathrm{ab}}$ \\
\hline $4 \%$ & $8460.1^{a b}$ & $6971.4^{\mathrm{NS}}$ & $13610.1^{\text {NS }}$ & $9795^{\mathrm{NS}}$ & $142.5^{\mathrm{NS}}$ & $73.5^{\mathrm{ab}}$ \\
\hline $6 \%$ & $19529.8^{a}$ & $3814.9^{\text {NS }}$ & $15474.8^{\text {NS }}$ & $8878.3^{\text {NS }}$ & $98.5^{\mathrm{NS}}$ & $79.6^{\mathrm{b}}$ \\
\hline $8 \%$ & $16064.5^{\mathrm{ab}}$ & $3199.8^{\mathrm{NS}}$ & $19347.3^{\text {NS }}$ & $7776^{\mathrm{NS}}$ & $75.3^{\mathrm{NS}}$ & $95^{a b}$ \\
\hline $10 \%$ & $14523.9^{\mathrm{ab}}$ & $3643.6^{\mathrm{NS}}$ & $21374^{\mathrm{NS}}$ & $7226.9^{\text {NS }}$ & $141.5^{\mathrm{NS}}$ & $72.8^{b}$ \\
\hline \multicolumn{7}{|l|}{ Stem } \\
\hline $0 \%$ & $3546.4^{\mathrm{NS}}$ & $507.2^{\mathrm{NS}}$ & $25422.7^{\mathrm{ab}}$ & $2746.3^{\mathrm{ab}}$ & $28.5^{\mathrm{NS}}$ & $113.6^{\mathrm{NS}}$ \\
\hline $2 \%$ & $4029.1^{\mathrm{NS}}$ & $384.6^{\mathrm{NS}}$ & $25568.2^{\mathrm{ab}}$ & $3823.1^{\mathrm{ab}}$ & $7.5^{\mathrm{NS}}$ & $106.3^{N S}$ \\
\hline $4 \%$ & $4051.5^{\mathrm{NS}}$ & $242.7^{\mathrm{NS}}$ & $27450^{\mathrm{ab}}$ & $3789.9^{\mathrm{ab}}$ & $3.8^{\mathrm{NS}}$ & $54^{\mathrm{NS}}$ \\
\hline $6 \%$ & $8776.9^{\text {NS }}$ & $312^{\mathrm{NS}}$ & $28994.2^{\mathrm{ab}}$ & $6799.4^{a}$ & $0^{\mathrm{NS}}$ & $99.3^{\mathrm{NS}}$ \\
\hline $8 \%$ & $6204.4^{\text {NS }}$ & $614^{\mathrm{NS}}$ & $34601.8^{a}$ & $4039.9^{a b}$ & $3.1^{\mathrm{NS}}$ & $110.1^{\mathrm{NS}}$ \\
\hline $10 \%$ & $4679.1^{\mathrm{NS}}$ & $157.8^{\mathrm{NS}}$ & $21773.2^{b}$ & $2162.6^{b}$ & $4.1^{\mathrm{NS}}$ & $38.3^{\mathrm{NS}}$ \\
\hline
\end{tabular}

${ }^{2}$ Means having a letter in common, within a column, are not significantly different at the $5 \%$ level of significance as indicated by Fishers protected LSD test. ${ }^{\mathrm{NS}}$ No significant difference as indicated by Fishers protected LSD test.

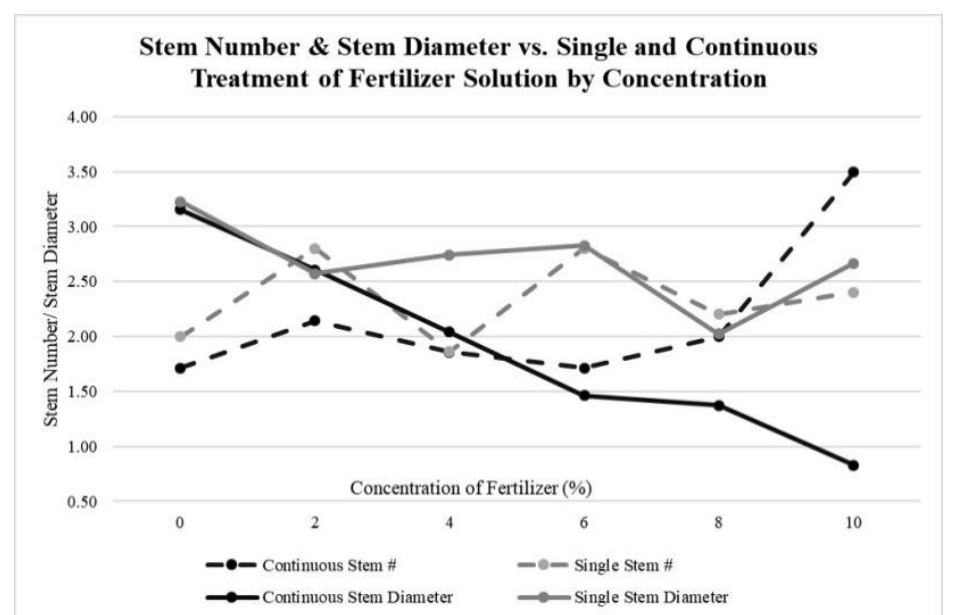

Fig 2. Mean stem number and stem diameter of Black Cohosh by single or continuous treatment of fusion 360 gold fertilizer solution by concentration. Stem Number: Continuous Treatment P Value is 0.9694; Single Treatment P Value is 0.5883. Stem Diameter: Continuous Treatment P Value is 0.0004; Single Treatment $P$ Value is 0.4336 . Significance is determined by Fishers protected LSD test and is considered significantly different at the $5 \%$ level of significance.

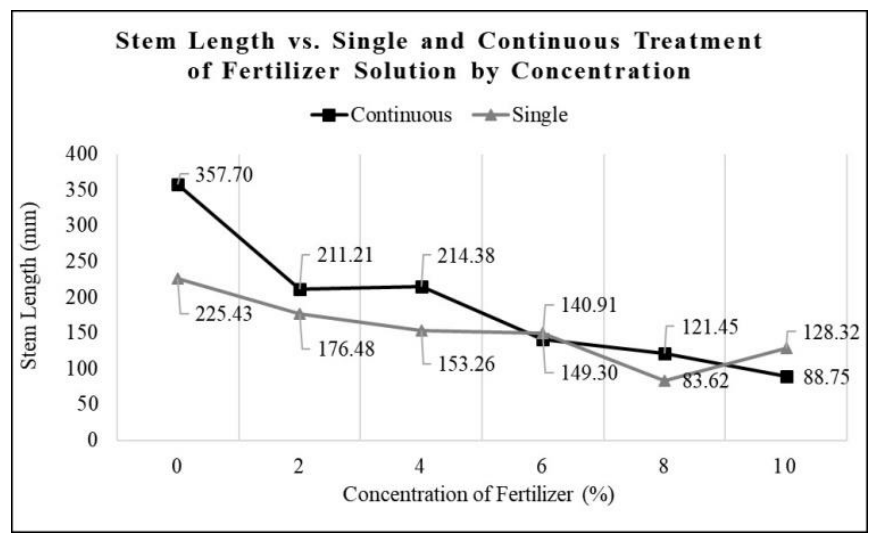

Fig 3. Mean stem length of Black Cohosh by single or continuous treatment of fusion 360 gold fertilizer solution by concentration. Continuous Treatment $P$ Value is 0.0003 ; Single Treatment P Value is 0.0011 . Significance is determined by Fishers protected LSD test and is considered significantly different at the $5 \%$ level of significance. 


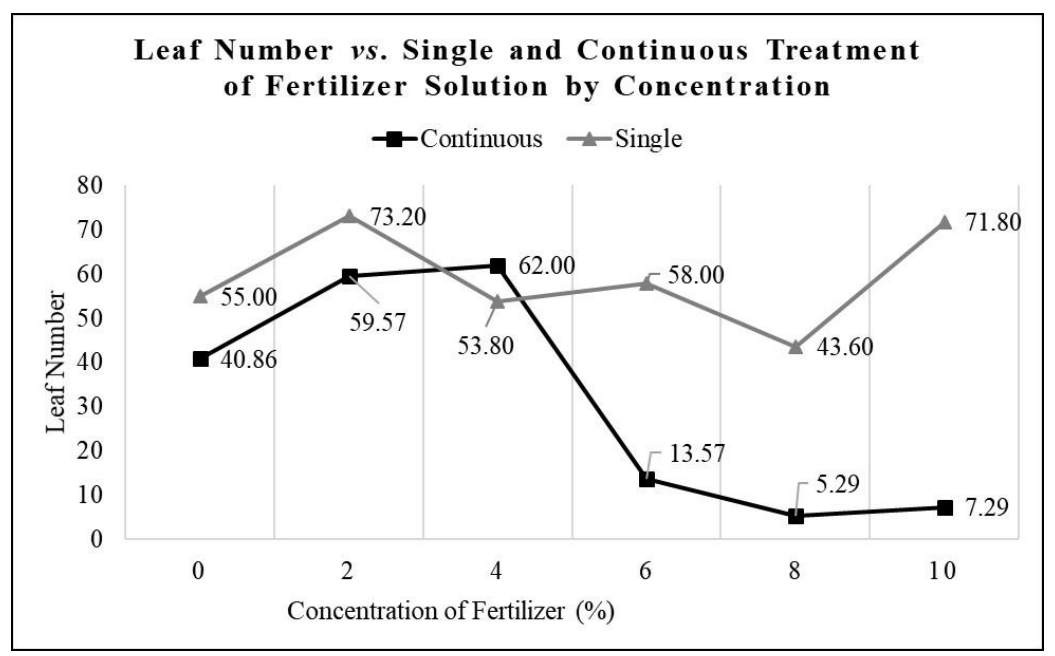

Fig 4. Mean number of leaves of Black Cohosh by single or continuous treatment of fusion 360 gold fertilizer solution by concentration. Continuous Treatment P Value is 0.0005 ; Single Treatment P Value is 0.8478 . Significance is determined by Fishers protected LSD test and is considered significantly different at the $5 \%$ level of significance.

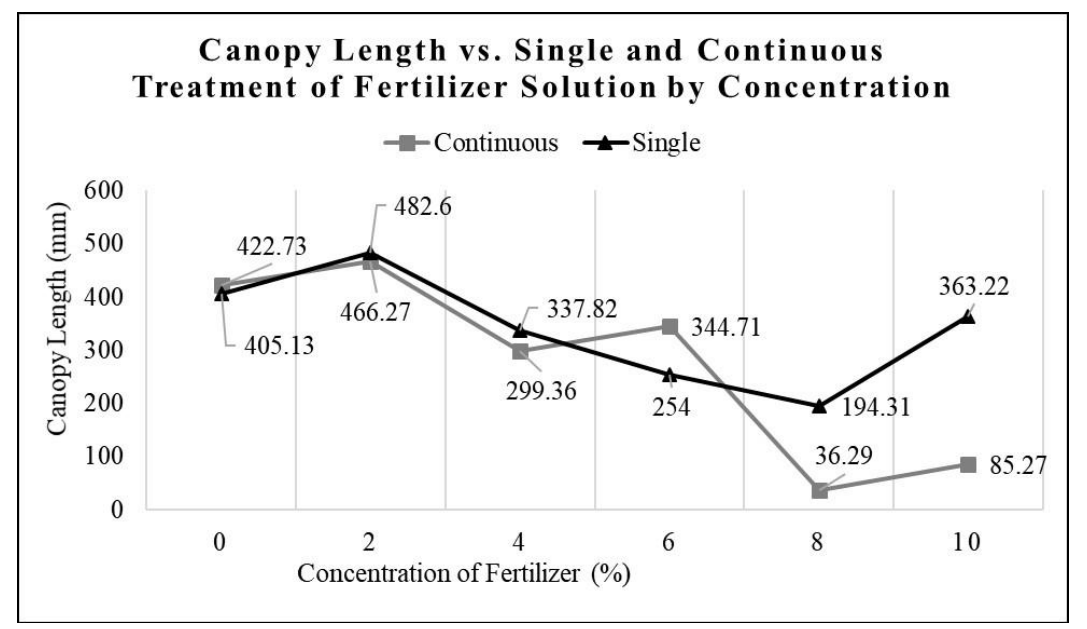

Fig 5. Mean canopy length of Black Cohosh by single or continuous treatment of fusion 360 gold fertilizer solution by concentration. Continuous Treatment P Value is 0.0333 ; Single Treatment $\mathrm{P}$ Value is 0.0855 . Significance is determined by Fishers protected LSD test and is considered significantly different at the $5 \%$ level of significance.

fertilizer concentration increased ( $0 \%$ to $10 \%)$, there were no significant changes in plant growth besides a decrease in stem length and rhizome fresh \& dry weight (Figs 1-5). This decrease in noticeable plant growth is most likely attributed to the fact that Black cohosh is a perennial, which during the first year of growth are known to have "reduced fertilizer needs due to their small initial size" (Mathe, 2015).

When Black cohosh was continuously fertilized, plant growth was reduced, except for the increase in number of stems per plant. In addition, our visual observations suggested that continuously fertilizing plants seemed to stimulate plants to reach maturity faster than single treatment exposure, which lead to the plant's death more quickly, and so the detriments far outweighed the benefits.

Understanding plant nutrient requirements and providing data-supported advice on fertilization is significantly important for growers to maximize their production, and thus the greatest possible income margin. This study helped provide specific information on certain required elements for optimal plant growth.

\section{Materials and Methods}

\section{Experimental Design}

Plants were arranged into two experimental designs, based on nutrient uptake and plant growth data. Plant growth data was measured using a Completely Randomized Split Plot Design, with two treatment groups, single exposure of fertilizer and continuous exposure of fertilizer, with six subplots for each concentration of fertilizer tested at $0 \%, 2 \%, 4 \%, 6 \%, 8 \%$ or $10 \%$ concentration. Nutrient uptake was measured using a Completely Randomized Design and was conducted only on the single exposure treatment group for each previously stated concentration. Plants were arranged as one seed rhizome per 2-gallon pot, placed under $80 \%$ shade cloth at the University Farm greenhouse, shade cloth was necessary to simulate a shaded environment, which as a shade tolerant plant, Black cohosh naturally grows under. 


\section{Experimental Procedure and Treatment Groups}

Treatment groups consisted of single exposure and continuous exposure groups, with six different concentrations of Fusion 360 Gold SunBurst Company Fertilizer solutions, which consisted of a control group of $0 \%$ fertilizer solution, and $2 \%, 4 \%, 6 \%, 8 \%$, and $10 \%$ fertilizer solution. Single exposure consisted of one application of fertilizer to soil before planting, while continuous exposure had one application of fertilizer every week for the duration of the growing season.

Single exposure, appropriate concentrations of Fusion 360 Gold SunBurst Company Fertilizer were added to soil, within each 2-gallon pot, one time; initial application of fertilizer was $1 \mathrm{~L}$ total solution volume. One week was allowed before planting seed rhizome, so that the soil and fertilizer could undergo chemical reactions, as recommended by our analytical research technician. There were five pots per concentration of fertilizer for a total of 30 pots. Pots were then placed under $80 \%$ shade netting in a greenhouse setting. For continuous exposure, appropriate concentrations of Fusion 360 Gold SunBurst Company Fertilizer were added to soil, within each pot, once a week. After initial fertilization ( $1 \mathrm{~L}$ of total fertilizer solution volume) one week was allowed before planting seed rhizome so that the soil and fertilizer could undergo chemical reactions. After planting of seed rhizomes, individual plants were fertilized once a week using $500 \mathrm{ml}$ of total fertilizer solution volume. There were seven 2gallon pots per concentration of fertilizer for a total of 42 pots. The plants were then placed under $80 \%$ shade netting in a greenhouse setting.

Nutrient Uptake Analysis and Plant Growth Data:

Samples for Inductively Coupled Plasma Optical Emission Spectroscopy Analysis (ICP-OES Analysis) were taken at five stages of the plants' life cycle. ICP-OES Analysis was only done on plants exposed to a single treatment of Fusion 360 Gold SunBurst Company Fertilizer and was conducted for each concentration measured. These stages were stage 1 (soil sample before exposure to fertilizer treatment; stage 2 (soil sample taken one week after application of fertilizer treatment but before planting); stage 3 (soil sample taken after more than $75 \%$ of pots exhibited new growth); stage 4 (leaf, stem, and root tissue samples taken after more then $90 \%$ of plants had reached full maturity); and stage 5 (soil sample after plants had died or gone into dormancy).

Stage 1 consisted of collecting a soil sample of the original potting mix, before it was treated with fertilizer, to provide a baseline of the elements and their concentration levels in the test soil. Stage 2 soil samples were collected after soil was treated with fertilizer by hand mixing, and then allowed to bind with soil for a one-week duration. This allowed the fertilizer and soil to undergo chemical reactions before Black cohosh rhizomes were planted and developed a standard on how different concentrations of fertilizer would affect the total amount of elements within the soil. Stage 3 soil samples were collected after more than $75 \%$ of plants experienced new growth and were compared to Stage 2 samples to determine how much of each element was being taken up by the plant and whether there were any elements within this fertilizer that the plant did not need, or were not being taken up. Stage 4 leaf, root, and stem tissue samples were collected after $90 \%$ of the plants had reached full maturity. At this stage of growth, root, stem and leaf samples were collected to determine the distribution of elements throughout the various parts of the plant. This helped to determine where the elements were located within the plant and what they were potentially being used for as well as determine a fertilization strategy for Black cohosh based on what the plant was taking up. Stage 5 soil samples were collected after plants were either dead or had gone into dormancy to determine how much of each element was still in the soil and if there was an increase or decrease of element composition as plants reached the end of their life cycle.

Sample digestion and analysis was conducted by employees in the Analytical Service Lab at North Carolina Agriculture \& Technical State University. Plant samples were placed in the dryer at 55 degrees $C$ for one week and then ground down into a fine powder at the University Farm to be measured. Soil and tissue samples were measured to 0.2 grams (- $0.01 \mathrm{~g}$, cannot be more than $0.2 \mathrm{~g}$ ) and placed in labeled, $50 \mathrm{ml}$ centrifuge tubes before being sent to the lab. Elements analyzed were taken from the Fusion 360 Gold SunBurst Company Fertilizer label and were Potassium (Soluble Potash $\mathrm{K}_{2} \mathrm{O} 2.00 \%$ ), Calcium $(2.20 \%)$, Magnesium $(0.75 \%)$, Iron $(0.10 \%)$, Manganese $(0.06 \%)$, and Zinc $(0.12 \%)$.

Elemental measurements were then sent back in Total PPM and converted to $\mathrm{mg} / \mathrm{kg}$ using the calculation below.

Total Element Amount $\left(\frac{\mathrm{mg}}{\mathrm{kg}}\right)=$

Total PPM of Element $\times$ Final Solution Volume $(\mathrm{ml})$ Initial Weight of Plant Tissue (g)

The following was determined for each part of the plant: most abundant element per concentration; least abundant element per concentration, percentage of each element per concentration, trends of each element per concentration. Stages of the plants life cycle were compared to determine how each element was taken up by the Black cohosh during its life cycle, accordingly, data were analyzed using Statistical Analysis Software (SAS) University Edition and Microsoft Excel. Plant Growth Data were measured when plants reached full maturity (stage 4) of growth for the single exposure and continuous exposure treatments. Rhizome fresh and dry weight $(\mathrm{g})$, stem length $(\mathrm{mm})$, stem diameter $(\mathrm{mm})$, number of leaves, and number of stems were also measured. These data were used to determine trends between element composition, concentration of fertilizer, and plant growth of Black cohosh.

\section{Conclusion}

Continuously fertilizing Black cohosh reduced plant growth and rhizome yield, except for the number of stems produced per plant, and visual observations indicate that continuously fertilizing plants stimulated plant to maturity faster than a single treatment. However, since this lead to the plant's premature death, it was determined that the detriments outweighed the benefits. Nutrient uptake analysis indicated that Black cohosh mainly utilizes calcium, potassium, magnesium and zinc as it fully matures, as well as manganese during its initial growing stage until full maturity. Iron was not absorbed with the same tenacity, but this may have been 
because of soil $\mathrm{pH}$, causing iron to become insoluble and unavailable for the plants to absorb (Morrissey and Guerinot 2009).

Potential growers should focus on setting a sparse fertilizing schedule with lower concentrations of fertilizer solution. Excessively fertilizing plants is not advantageous in plant development because of limited plant growth. Have fertilizer tailored to contain calcium, magnesium, potassium and zinc for growth and development.

\section{Acknowledgments}

This research was supported by NCA\&T's Agricultural Research Program through USDA/NIFA/Evans-Allen projects: NC.X280-514-130-1, and NC.X313-5-18-130-1. We also acknowledge the SunBurst Company for providing the Fusion 360 Gold SunBurst Company Fertilizer solution for the fertilizer and nutrient uptake research. The authors also wish to express their gratitude to Mr. Daniel M. Nonte (Interim Director of Agricultural Communications) for his review and edit on the manuscript.

\section{References}

Adam, K (2002) Ginseng, Goldenseal, and Other Native Roots: Horticultural Technical Note R. Earles, ed. Appropriate Technol Transfer for Rural Areas. 13 June 2019. www.attra.ncat.org.

Burdette, JE, Liu, J, Chen, SN, Fabricant, DS, Piersen, CE, Barker, EL, Pezzuto JM, Mesecar A, Van Breemen RB, Farnsworth NR, Bolton, JL (2003) Black cohosh acts as a mixed competitive ligand and partial agonist of the serotonin receptor. J Agr Food Chem. 51(19): 5661-5670.

Crouse, D (2018) North Carolina extension gardener handbook. Moore \& L. K. Bradley, eds., Raleigh, NC: Published by NC State Extension, College of Agri and Life Sci., NC State University.

Foster, S (2013) Exploring the peripatetic maze of Black Cohosh adulteration: a review of the nomenclature, distribution, chemistry, market status, analytical methods, and safety. HerbalGram. (98):32-51. 5 June 2019. http://cms.herbalgram.org/herbalgram/issue98/hg98featblackcohosh.html.

Gardner, Z (2002) Cultivation and marketing of woodland medicinal plants- spring 2002 special supplement on agroforestry. Northeast Organic Farming Assoc. 13 June
2019.

http://www.nofa.org/tnf/sp02/supplement/medicinalni.pdf. Jakobsen, ST (1993) Interaction between plant nutrients: III. Antagonism between potassium, magnesium and calcium. Acta Agriculturae Scandinavica, Section B - Soil \& Plant Science. 43(1):1-5. DOI: 10.1080/09064719309410223.

Imelouane, B, Tahri, M, Elbastrioui, M, Aouinti, F, \& Elbachiri, A (2011) Mineral contents of some medicinal and aromatic plants growing in eastern Morocco. J of Materials and Env Science. 2(2): 104-111. Retrieved January 28, 2019, from https://www.jmaterenvironsci.com/Document/vol2/13JMES-52-2010-Emelouane.pdf.

Mathe, A (2015) Medicinal and aromatic plants of the world: scientific, production, commercial and utilization aspects. Dordrecht: Springer. doi:10.1007/978-94-017-9810-5

Morrissey, J, and Guerinot ML (2009) Iron uptake and transport in plants: the good, the bad, and the ionome. Chemical reviews. 109(10): 4553-4567. PMC. Web. 21 Apr. 2018.

Predny, M.L., P. DeAngelis, and J. Chamberlain (2006) Black cohosh (Actaea racemosa): an annotated bibliography GEN. TECH. Rep. SRS-97. Southern Research Station. 1-99. 12 June 2019. https://www.srs.fs.usda.gov/pubs/gtr/gtr_srs097.pdf.

Reid, RJ (2001) Mechanisms of micronutrient uptake in plants. Australian Journal of Plant Physiology. 28(7): 661-668. 19 December 2019. http://www.publish.csiro.au/fp/PP01037

Queralt I, Ovejero M, Carvalho ML, Marques AF, Llabres JM (2005) Quantitative determination of essential and trace element content of medicinal plants and their infusions by XRF and ICP techniques. X-Ray Spectrometry. 34(3): 213-217. $12 \quad$ December 2019. https://onlinelibrary.wiley.com/doi/abs/10.1002/xrs.795

Schwalbach, M (2005) Forest Service Handbook North Carolina National Forest (Region 8) Asheville, North Carolina. (r8_nc_2409.18-2005-3). Asheville, NC.

Switzerland, World Health Organization, Department of Essential Drugs and Medicines Policy (EDM) (2003) WHO guidelines on good agricultural and collection practices (GACP) for medicinal plants. 1-80. World Health Organization.

Tiwari, AK, Rao JM (2002) Diabetes mellitus and multiple therapeutic approaches of phytochemicals: present status and future prospects. Current Science. 83(1): 30-38. 19 December 2019. https://pdfs.semanticscholar.org/cdc2/5995e6980f30c75d6a ec55441fd3612cee8a.pdf 